\title{
METHODOLOGICAL APPROACHES TO ASSESSING THE SOCIAL RESPONSIBILITY LEVEL IN THE FIELD OF SUPPLY CHAIN MANAGEMENT
}

\author{
Rustam Aslanzade 1, 2,3 \\ ${ }^{1}$ Azcond LLC, Baku, Azerbaijan \\ ${ }^{2}$ Azerbaijan State Oil and Industry University, Baku, Azerbaijan \\ ${ }^{3}$ ISMA University, Riga, Latvia \\ e-mail: rustam.aslan@gmail.com
}

Received: 20 February 2021; Accepted: 26 April 2021 Published: 01 May 2021

\begin{abstract}
The article reveals the essence of such a sphere of entrepreneurial activity as Supply Chain Management. An important aspect of supply management is the implementation of the concept of Corporate Social Responsibility (CSR), which is an integral feature of modern civilized business. The aim of the article is to develop a methodological approach to assessing the level of social responsibility of Supply Chain Management' company. Based on the previously proposed approaches to assessing the social responsibility of a company, the author proposes an adapted approach to assessing the social responsibility of supply chains' company. The integral index for SR SCM level assessment combines the following indicator blocks: a responsible producer of goods and services; a responsible business partner, a responsible participant in social and labour relations; a responsible participant in socio-economic and political relations with the state. The article proposes a methodology for assessing socially responsible Supply Chain Management based on the calculation of the integral index, which combines the following indicator blocks: the index of compliance of the supplied raw and other materials, components and accessory parts to the environmental standards; environmental sustainability index for supply chain's transport support; index of products (services) compliance with international quality standards. Assessment of the companies' corporate responsibility and their supply chains from their policies' perspective is possible, if it is based on the implementation of the Key Performance Indicators system, which will allow controlling the level of achievement for corporate responsibility objectives within the framework of the company's activities.
\end{abstract}

Keywords: corporate social responsibility (CSR), supply chain management, integral index of the social responsibility of supply chains.

JEL classification: M14, M21, C89

Citation:

Aslanzade, R. (2021). Methodological approaches to assessing the social responsibility level in the field of supply chain management. Access to science, business, innovation in digital economy, ACCESS Press, 2(2): 162-174.

https://doi.org/10.46656/access.2021.2.2(4)

\section{INTRODUCTION}

Assessment of the social responsibility level in the field of supply chain management (SCM) is an important component in the further implementation of the corporate social responsibility concept, its genesis, and development of individual applied aspects, thus ensuring the companies' balanced development in different industries. 
The building industry (and in particular, the production and installation of heating, ventilation and air conditioning systems) has a number of features that affect the implementation of socially responsible SCM practices. They are connected, first of all, with the fact that in the process of selecting suppliers and their products the emphasis is on the environmental sustainability of raw materials and technologies, and their compliance with the international quality standards. An important aspect is that there are virtually absent the wholesale consumers such as chains of building supermarkets and hypermarkets in the sale of manufacturers' products. Product sales are targeted to specific consumers.

Supply chain management is an important area in the implementation of the CSR concept in modern business. Building an end-to-end supply chain based on the principles of sustainable development is an urgent problem of modern business theory and practice.

\section{Materials and Methods}

The theoretical origins of the CSR concept in the system of entrepreneurial activity are laid down in the works of M. Allais, F. Burley, G. Bowen, M. Weber, P. Drucker, B. Carloff, E. Carnegie, F. Kotler (Kotler \& Lee, 2005), G. Minz, and other scientists. Classics are G. Bowen, K. Davis, A. Carroll, laid down in the 60 years of the twentieth century, the basic concepts of the theory of social responsibility. At present, the concept of CSR is further developed in the economic science and practice of many countries, these problems are developed by R. Akkerman, U. Buffet (Buffet, 2008), Y. Blagov, E. Grishnova, L. Laptev (Laptev, 2004), etc. Supply Chain Management (SCM) was seen as an important part of the overall management of the enterprise. A key SCM' role in increasing the effectiveness of its functioning have proved S.Chopra (Chopra, Meindl, 2016), Ivanov and Sokolov (2010), M.Christopher (Christopher, 2005), T.Harrison (Harrison, 2001), etc.

An increasing adherence to the principles of social responsibility is the global trend of business development in modern conditions. And although most companies directly decorate goals and policies aimed at corporate sustainability, only $20 \%$ of companies are focused on building the entire network with a high level of corporate social responsibility (Cecere, 2015). At the same time, an important scientific problem is the assessment of the level of social responsibility in the field of SCM (Chen \& Gong, 2013), (Kumar \& Wagle, 2014), (Managing Green Supply Chains: Best Practices and Long-term Solutions, 2012), (Prashant Kumar \& Subhash Wagle, 2014), (Wannenwetsch, 2005), which has not been enough researched in the literature. 
The aim of the article is to develop a methodological approach to assessing the level of social responsibility of SCM company. Based on the previously proposed approaches to assessing the social responsibility of a company, the author proposes an adapted approach to assessing the social responsibility of supply chains' company.

\section{Results and Discussion}

An important scientific problem is the corporate social responsibility assessment. The works of many foreign and national scientists are devoted to this subject, and in addition, the international standards of social responsibility have been developed. All existing approaches to assessing the social responsibility at the micro-level can be classified according to the following criteria:

1) depending on the indicators used, the approaches are based on qualitative and quantitative estimates;

2) depending on the approach used as the basis for the calculations such as index, rating, etc.;

3) depending on the assessment purpose (for compiling social reporting), the most common standards for preparing social reporting) are the following: The Communication on Progress (COP); Global Reporting Initiative (GRI); Account Ability (report on AA1000 standards)), for managerial solutions, for strategic and tactical planning, etc.

However, it's necessary to note that despite rather significant scientific potential in the field of social responsibility, the problems of assessing the social responsibility level on certain fields of the company's activity still have considerable scope for theoretical, practical, methodological, and research works. Virtually, no methods have been developed for assessing the social responsibility in the field of supply chain management.

The methodology for assessing the companies' voluntary social responsibility is based on the CSR issues disclosed in the companies' non-financial reporting and rating in the field of social responsibility. The assessment is made based on the following components:

1) general and economic information about the company;

2) expenses for solving social issues of the company's employees and their families (as a percentage of revenue): medical care and maintaining a healthy lifestyle; family social support and employee benefits; assistance in housing provision; support for working veterans; training and personnel work costs; measures on labour protection and environmental safety;

3) expenses for social programs outside the company (as a percentage of revenue): expenses for the implementation of social programs in the framework of bilateral agreements between the company and the government; costs on social programs outside the company.

A methodological approach to assessing the social responsibility of building companies was proposed by V.V. Smachilo and V.A. Balyaba (Smachilo \& Balyaba, 2015). They proposed a list of estimated indicators for building companies' social responsibility with 47 indicators. These indicators are divided into 7 blocks 
with consideration of their specific features - "Organizational Management", "Human Rights", "Labour Practices", "Environment", "Responsible Business Practices", "Problems Related to Consumers", "Participation in the Communities' Life and Development". The methodology is based on involving of experts and rating, which is caused by the need to justify the estimated indicators and evaluate their values, which are multidirectional and diverse. The rating scale is from 1 (worst score) to 10 (best score). The best score can be characterized by both its high value and low, depending on the indicator type. The methodology for assessing the building companies' social responsibility includes the following steps:

1) substantiation of the list of indicators, by which the building company's social responsibility will be assessed in accordance with ISO 26000 based on a survey of scientists and the experts, who were the heads of the building companies' structural divisions;

2) calculation of the actual indicators' value;

3) verification of the indicators compliance with the established criteria and assessment. According to the audit results, the experts give scores from 1 to 10 for each indicator; then, the total score for all estimated indicators is evaluated (the maximum score is 470 points, of which 120 are qualitative indicators, 350 are quantitative indicators);

4) calculating the actual value of the company's social responsibility in points, and comparing it with the maximum possible value;

5) generating the company's social responsibility areas;

6) locating the area where the company is at present in order to establish the real situation for the company's social responsibility further development, to develop the necessary program of events.

Basing on the assessment findings, V.V. Smachilo and V.A. Balyaba (Smachilo \& Balyaba, 2015) recommend distinguishing the following: an area of company's social irresponsibility, a point of minimum social responsibility, an area of the company's social responsibility of a middle level, an area of the company's high level social responsibility. Thus, if the company scored less than 120 points in the assessment, and it is considered as socially irresponsible. A socially irresponsible company is a business entity that does not meet the minimum requirements of legislative and regulatory provisions on social responsibility. The remaining points are evenly distributed between the medium and high levels of social responsibility, which allows generating the appropriate areas and ranges for social responsibility.

The Supply Chain Management is closely related to marketing, especially in terms of assessing the company's social responsibility. Social responsibility in the company's activities is implemented as a result of the relevant policies. However, providing the information about the company's commitment to social responsibility principles to consumers, stakeholders, and the general public is a marketing function. 
I stage. Studying methods for evaluating the companies' CSR and SR SCM, and verifying for compliance with international social responsibility standards

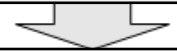

II stage. Selecting most significant indicators, and assessing by experts

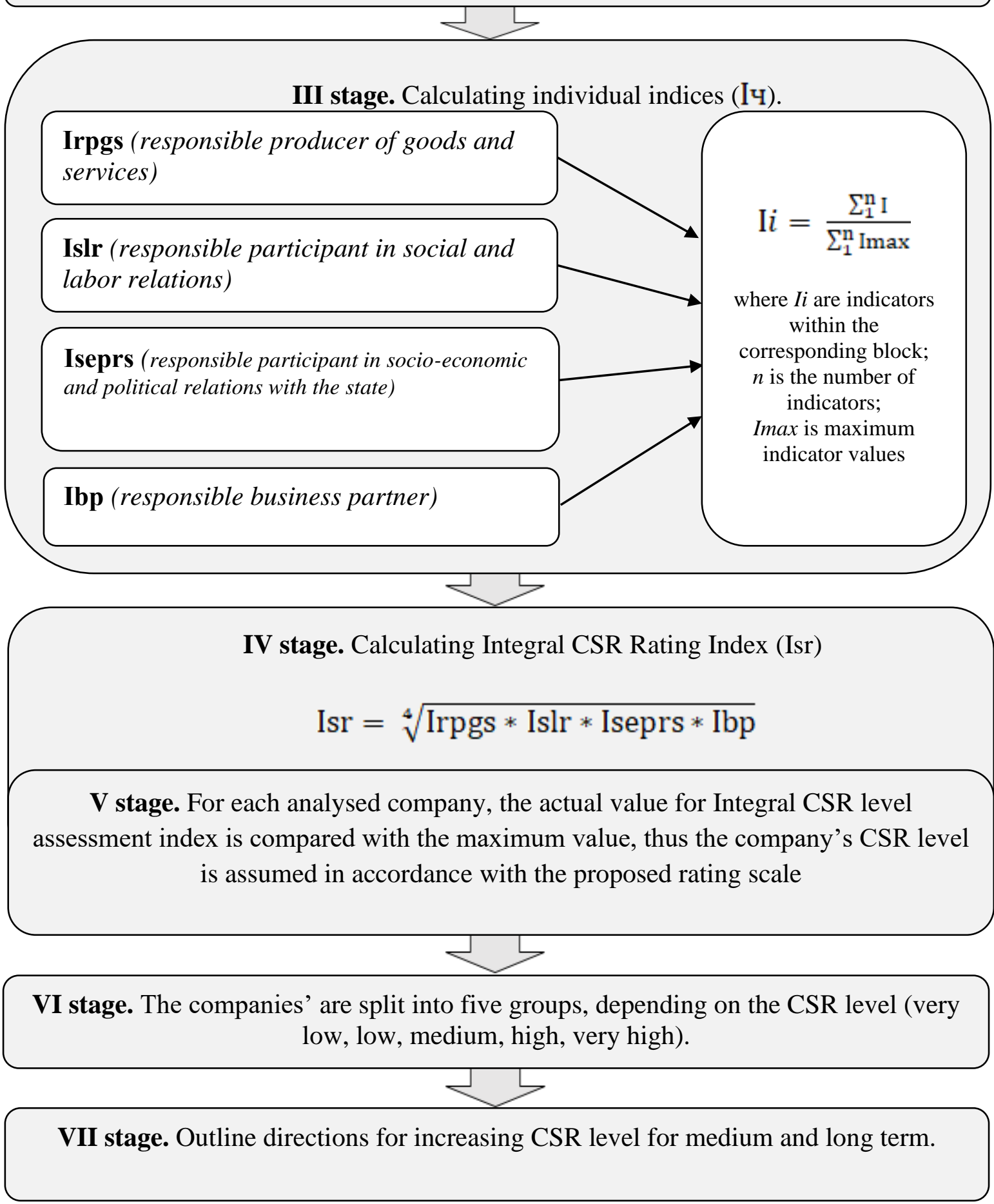

Fig. 1. Theoretical and methodological approach to assessing the corporate social responsibility level in building corporations

Source: Developed by the author. 
Therefore, when developing the instruments for assessing social responsibility of such a company's activity important component as supply chain management, we will inevitably include the marketing elements.

Thus, taking into account the specific features of the socially responsible marketing and the approaches to its assessment existing in the scientific literature, we propose to define the social responsibility level in supply chain management basing on an expert survey of both scientists and practitioners working in the enterprises under study. There are 7 stages of assessment of the companies' CSR level (see Fig. 1).

I Stage. The study of methods for evaluating the companies' CSR and SR SCM, and verifying for compliance with the international standards of social responsibility

Based on the results of this study, a general list of indicators is formed, and then it is submitted for consideration by experts.

II Stage. Selection of the most significant indicators, and their evaluation by independent experts. We developed a system of indicators for calculating the integral index for assessing the company's CSR level basing on a survey of experts who are specialists in the supply chain management and marketing, corporate social responsibility, and leading scientists working in this area (Table 1).

Table 1. The system of indicators for calculating integral index for evaluating the CSR level

\begin{tabular}{|c|c|}
\hline Indicator block name & Assessment Aspects / Indicators \\
\hline \multirow{5}{*}{$\begin{array}{l}\text { Responsible } \\
\text { goods and services } \\
\text { manufacturer }\end{array}$} & Offering safe products to the market; \\
\hline & refusal to use environmentally harmful substances in production \\
\hline & Energy efficiency; \\
\hline & Certification of products according to international standards; \\
\hline & using environmentally friendly, quality, and cheap packaging. \\
\hline \multirow{6}{*}{$\begin{array}{l}\text { Responsible Business } \\
\text { Partner }\end{array}$} & Providing reliable information about the products or services; \\
\hline & Building Responsible Supply Chains \\
\hline & using safe technologies for transportation and product marketing; \\
\hline & Using Ethical Advertising \\
\hline & Transparent pricing \\
\hline & Arranging long-term relationships with consumers and suppliers. \\
\hline Responsible & Ensuring decent pay and working conditions; \\
\hline
\end{tabular}




\begin{tabular}{|c|c|}
\hline \multirow[t]{3}{*}{$\begin{array}{l}\text { participant in social } \\
\text { and labour relations }\end{array}$} & $\begin{array}{l}\text { Transparency of information regarding the company's personnel strategy for } \\
\text { all personnel; }\end{array}$ \\
\hline & completeness and timeliness of wage payments; \\
\hline & Implementation of social projects for the company's personnel. \\
\hline \multirow{4}{*}{$\begin{array}{l}\text { Responsible } \\
\text { participant in socio- } \\
\text { economic and } \\
\text { political relations } \\
\text { with the state }\end{array}$} & Compliance with applicable laws \\
\hline & Timely and transparent tax payment; \\
\hline & subject to fair competition rules; \\
\hline & Participation in state social projects implementation. \\
\hline
\end{tabular}

III Stage. Calculation of particular indices. Basing on an expert survey, the individual indices (Ii) are calculated for the following groups of indicators:

responsible producer of goods and services (Irpgs), responsible participant in social and labour relations (Islr), responsible participant in socio-economic and political relations with the state (Iseprs), responsible business partner (ibp) according to the following formula:

$$
\mathrm{I} i=\frac{\sum_{1}^{\mathrm{n}_{1}} \mathrm{I}}{\sum_{1}^{\mathrm{n}} \operatorname{Imax}}
$$

where I are indicators within the corresponding block; $\mathrm{n}$ is the number of indicators; Imax is maximum indicator values.

IV Stage. Calculation of the integral CSR level evaluation index (Isr), which is defined as the geometric mean of the particular indices:

$$
\text { Isr }=\sqrt[4]{\operatorname{Irpgs} * \text { Islr } * \text { Iseprs } * \text { Ibp }}
$$

V Stage. For each company under study, the actual value of the CSR level assessment integral index is compared with the maximum value and the company's CSR level is assumed in accordance with our proposed rating scale (Table 2).

VI Stage. The companies' sorting into 5 groups, depending on the CSR level (very low, low, medium, high, very high).

Such sorting of companies into groups will make it possible to better compare them, find common problems in their activities and the ways to solve them, improve conceptual approaches to the further 
implementation of the corporate social responsibility concept both in the companies and individual enterprises.

Table 2. Rating scale for CSR level

\begin{tabular}{|c|c|}
\hline SR SCM level & Isr SCM value \\
\hline very low & from 0 to 0.2 \\
\hline low & from 0.2 to 0.4 \\
\hline medium & from 0.4 to 0.6 \\
\hline high & from 0.6 to 0.8 \\
\hline very high & from 0.8 to 1.0 \\
\hline
\end{tabular}

VII stage. Identifying the directions for increasing CSR level in the medium and long term.

Raising the CSR level implies the implementation of such important aspects as: effective interaction with external stakeholders, ensuring socially responsible SCM, setting stable business relationships and ensuring the quality of products and their components at all supply chain stages.

Socially responsible SCM for the company, first of all, means forming relations with business partners on the principles of compliance with agreements, professional performance standards, and financial responsibility. Such a company should conduct its activities in accordance with applicable law and comply with the concluded agreements. The company has got fame on the national or international market, as the company's owners care about its image, the financial statements are transparent, the company's charity is not ostentatious, and the company's positive reputation is stable (Elkington, 1998).

The world business practice has gained extensive experience in evaluating companies' CSR. Moreover, the general trend is spreading the CSR international standards in open systems that allow each company to voluntarily publish its reports on social responsibility. These international CSR standards include: ISO 26000:2010 (Guidance on social Responsibility) ${ }^{1}$, OHSAS 18001 (Occupational Health and Safety Management Systems) ${ }^{2}$, RG Sustainability Reporting Guidelines G 3.1², SA8000 (Social Accountability International 8000) ${ }^{4}$, GRI (Global Reporting Initiative) (Standarts GRI), etc.

5 blocks of standards are presented in the international standards system GRI (Global Reporting Initiative): GRI 102 - information about an organization, GRI 103 - information about the management

\footnotetext{
${ }^{1}$ https://isotc.iso.org/livelink/livelink/fetch/2000/2122/830949/3934883/3935837/3974907/N172_ISO_DIS_26000_E_.pdf?nodeid $=8385467 \&$ vernum $=0$

${ }^{2} \mathrm{http} / / /$ www.assistem.kiev.ua/doc/ohsas 18001-2007.pdf

${ }^{3}$ https://www.assistem.kiev.ua/doc/ohsas18001-2007.pdf

${ }^{4} \mathrm{https} / / /$ www.daikin.com/csr/information/influence/hfc32.html
} 
system, GRI 200 - economic information, GRI 300 - environmental information, GRI 400 - social standards (Standarts GRI). The GRI 308 group of standards addresses the suppliers' environmental performance in the supply chain. In accordance with them, it is recommended that the companies when preparing a report shall provide the following information about their approach to the supply management environmental assessment:

- the systems used to screen new suppliers using environmental criteria and relevant criteria for environmental sustainability used to screen new suppliers;

- the processes used (such as the necessary prudence) in order to identify and evaluate the actual and potential negative environmental impacts in the supply chain;

- how the organization determines and prioritizes the suppliers' selection in the context of environmental impact assessments;

- the actions taken to eliminate significant actual and identified potential negative environmental impacts in the supply chain, and whether any actions have been taken to prevent, mitigate, or correct these impacts;

- how the measures in contracts with suppliers facilitate the prevention, mitigation and correction of significant actual and potential negative environmental impacts, including goals and tasks, are established;

- whether the suppliers are motivated and rewarded to prevent, mitigate, and recover significant actual and potential negative impacts on the environment;

- the practice of evaluating and auditing suppliers, their products, and services using environmental criteria;

- a list of types, systems, scope, frequency, assessment intensity, and certified audit, including the supply chains;

- the systems for assessing potential negative consequences of suspending or terminating relations with a supplier, if one's activity environmental impacts and harm-reduction strategy do not comply with the ecological responsibility standards.

Accordingly, the following indicators can be used:

308-1 - part of new suppliers (in percent's) who were verified as users of environmental criteria.

308-2 - the information regarding the company's awareness of significant actual and potential negative environmental impacts in the supply chain:

a) the number of suppliers evaluated for environmental impacts;

b) the number of suppliers identified as those having significant actual and potentially negative environmental impacts;

c) the significant actual and potential negative environmental impacts identified in the supply chain; 
d) the part of suppliers (in percent's) identified as those that provide significant actual and potentially negative impacts on the environment, and with which the improvements as a result of the assessment were agreed;

e) the part of suppliers (in percent's) identified as those that provide significant actual and potentially negative impacts on the environment, with which the relationships were suspended or terminated as a result of the assessment, and the reasons why (Standarts GRI).

Based on generalization of existing approaches, we proposed to evaluate socially responsible SCM (SR SCM) within the company's general system of social responsibility assessment basing on the following system of performance indicators within the established supply chains:

1) Irm - the index that shows compliance of the supplied raw materials and other materials, components and accessory parts with the environmental standards;

2) Iet - environmental sustainability index of transport support for the supply chain;

3) Irisq - index of product compliance with the international quality standards.

The index of compliance for the supplied raw materials is calculated as the share of raw materials and other materials, components and accessory parts with certificates of compliance with the environmental standards in the total amount of raw materials and components used:

$$
I r m=\frac{R M}{W M}
$$

where $R M$ is the amount of raw materials and other materials, components and accessory parts complying with environmental (or international standards);

$W M$ - the total amount of the supplied raw materials and other materials, components, and accessory parts.

The environmental sustainability index of transport support for the supply chain is defined by the number of transport and logistics companies that meet high environmental standards in the overall supply chain relative to the total number of transport and logistics companies:

$$
\text { let }=\frac{T R}{W T}
$$

where $T R$ is the number of transport companies that meet environmental or international standards;

$W T$ is the total number of vehicles included in the supply chain.

The index of the product's compliance with international quality standards that indicates the quantity of products that meets international quality standards in the total amount of products: 


$$
\text { Irisq }=\frac{P R}{W P}
$$

where $P R$ is the number of products that meet international standards (describing, if available, international quality certificates; certificates of compliance with international environmental standards, and other types of voluntary certification for products or business processes for a supplier company);

$W P$ is the total product output.

As a result, we have developed a theoretical and methodological approach to assessing the level of SR SCM in companies, which can be applied in many industries. The general approach to assessing CSR is to calculate the integral index by the forms of manifestation social responsibility in the context of the following groups of indicators: a responsible producer of goods and services, a responsible participant in social and labour relations; a responsible participant in socio-economic and political relations with the state; a responsible business partner. Thus, SCM is an important area of social responsibility implementation, which requires specific approaches to its assessment. We proposed assessing the level of social responsibility in this area using a fractional index calculated basing on sub-indexes within the formed supply chains' mechanism: the index of compliance of raw materials and other materials, components and accessory parts to environmental standards; environmental sustainability index for the supply chain's transport support; index of compliance for products (services) with international quality standards.

In general, an integrated assessment of the companies' social responsibility is possible only if there is provided reliable statistical information on them, which requires developing new standards for generation of analytical data, reduced to one form. In our opinion, the assessment of companies' corporate responsibility and their supply chains from their policy perspective is even more important. Based on this, we consider it appropriate to introduce the Key Performance Indicators system, which can be adapted by each company to its own characteristics and specific goals. The assessment of the company's internal environment based on four main criteria: finance, customers, staff, and internal business processes, seems to be the most reliable.

\section{CONCLUSION}

Thus, the adoption of the social responsibility concept should be the main idea that permeates the company's main objectives - from strategy formation to decision making within the framework of the companies' operational activities. The system of indicators we proposed in the study for calculating the integral index for SR SCM level assessment combines the following indicator blocks: a responsible producer of goods and services; a responsible business partner, a responsible participant in social and labour relations; a responsible participant in socio-economic and political relations with the state. Methodological approaches to assessing SR SCM are proposed basing on a fractional index that is integrating the following indices: the index of compliance of the supplied raw and other materials, components and accessory parts to the environmental 
standards; environmental sustainability index for supply chain's transport support; index of products (services) compliance with international quality standards.

An integrated assessment of the social responsibility for several companies is possible only if reliable statistical information on them is available. Assessment of the companies' corporate responsibility and their supply chains from their policies' perspective is possible, if it is based on the implementation of the Key Performance Indicators system, which will allow controlling the level of achievement for corporate responsibility objectives within the framework of the company's activities.

\section{Conflict of interests}

The authors declare no conflict of interest.

\section{References}

Buffet, W. (2008) Jesse ob investicijah, korporativnyh finansah i upravlenii kompanijami, 268 s. Retrieved from: http://muganfx.com/uploads/books/book_1271318186.pdf

Cecere, L. (2015). Building the Green Supply Chain. Retrieved from: http://www.supplychain247.com/paper /building_the_green_supply_chain

Chen, T., Gong, X. (2013). Performance evaluation of a supply chain network. Procedia Computer Science, 17, pp. $1003-1009$.

Chopra, S., Meindl, P. (2016). Supply Chain Management: Strategy, Planning, and Operation. Pearson Education Inc. Limited.21. Chandler, D. (2016). Strategic corporate social responsibility: sustainable value creation. United States of America: SAGE Publications.

Christopher, M. (2005) Logistics and Supply Chain Management: Creating Value-Adding Networks. Financial Times Prentice Hall, Dorchester Retrieved from: http://www.icesi.edu.co/blogs/supplychain0714/files/2014/07/ Martin_Christopher_Logistics_and_Supply_Chain_Management_4th_Edition_2011-1.pdf

Elkington, J. (1998). Partnerships from cannibals with forks: The triple bottom line of 21st-century business. Environmental Quality Management, 8(1), 37-51.

Global Compact Communication on Progress (COP). (2008). The Practical Guide to the United Nations. Retrieved from: file:///C:/Users/User/Downloads/Practical_Guide_2008_En.pdf

Harrison, T.P. (2001) Global Supply Chain Design. Retrieved from: https://www.researchgate.net/ profile/Terry_Harrison2/publication/225216541_Global_Supply_Chain_Design/links/00463518336836d4ad00000 0/Global-Supply-Chain-Design.pdf

International standart ISO/DIS 26000. Retrieved from: https://isotc.iso.org/livelink/livelink/fetch/2000/2122/830949/ 3934883/3935837/3974907/N172 ISO DIS 26000 E .pdf?nodeid=8385467\&vernum $=0$

Ivanov, D., Sokolov, B. (2010). Adaptive Supply Chain Management. - L.: Springer. - ISBN 978-1-84882-951-0

Kotler, P., Lee, N. (2005) Corporate social responsibility: Doing the most good for your company. 302 p.

Kumar, P., Wagle, S. (2014). Greening the Supply Chain. Retrieved from: http://www.supplychain247.com/ paper/greening the supply chain\#register

Laptev, L. (ed.) (2004) Social'naja otvetstvennost' biznesa. Korporativnaja otchetnost' - novyj faktor vzaimodejstvija biznesa i obshhestva. M., $310 \mathrm{p}$.

Linde, I., Philippov, D. 2020. Applying Lean Six Sigma in construction. World practice experience. Access to science, business, innovation in digital economy, ACCESS Press, 1(2): 103-111. https://doi.org/10.46656/access.2020.1.2(2)

Linde, I., Philippov, D. 2021. What do your customers think about? To guess or to know? Access to science, business, innovation in digital economy, ACCESS Press, 2(1): 17-27. https://doi.org/10.46656/access.2021.2.1(2)

Managing Green Supply Chains: Best Practices and Long-term Solutions. (2012). Retrieved from: https://knowledge.wharton.upenn.edu/article/managing-green-supply-chains-best-practices-and-long-term-solutions/ 
OHSAS 18001-2007. (2008). Sistemi menegmenta bezopasnosti truda. Retrieved from: http://www.assistem.kiev.ua/doc/ohsas18001-2007.pdf

Prashant Kumar \& Subhash Wagle. (2014). Greening the Supply Chain. Retrieved from: http://www.supplychain247.com/paper/greening_the_supply_chain\#register

R-32: The Most Balanced Refrigerant for Stationary Air Conditioners and Heat Pumps. Retrieved from: https://www.daikin.com/csr/information/influence/hfc32.html

Smachilo, V.V.; Balyaba, V.A. (2015). Otsenka socialnoi otvetstvennosti stroitelnih predprijatij. Scientific discussion. №6. Pp. 162-169 Retrieved from: https://cyberleninka.ru/article/v/otsenka-sotsialnoy-otvetstvennosti-stroitelnyhpredpriyatiy

Social Accountability 8000. Retrieved from: https://sa-intl.org/wp-content/uploads/2020/02/SA8000-2014-GuidanceDocument.pdf

Standarts GRI. Retrieved from: https://www.globalreporting.org/standards/gri-standards-download-center/

\section{About the author}

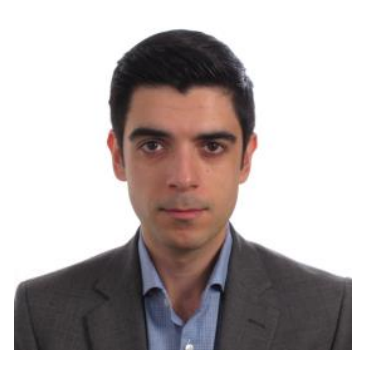

\section{Rustam ASLANZADE}

Deputy Director at Azcond LLC (Baku, Azerbaijan), Adjunct lecturer at Azerbaijan State Oil and Industry University (Baku, Azerbaijan), PhD Student ISMA University (Riga, Latvia), Scientific interest: supply chain management

ORCID ID: https://orcid.org/0000-0001-5067-639X

Copyright $(\odot 2020$ by author(s) and ACCESS Publishing Press This work is licensed under the Creative Commons Attribution International License (CC BY) 